\title{
LEPIDIUM BARNEOUDIANUM SUTORÝ: A NEW NAME FOR THE CHILEAN ENDEMIC SPECIES LEPIDIUM BREVICAULE BARN. (BRASSICACEAE)
}

\section{LEPIDIUM BARNEOUDIANUM SUTORÝ: UN NUEVO NOMBRE PARA LA ESPECIE ENDEMICA CHILENA LEPIDIUM BREVICAULE BARN. (BRASSICACEAE)}

\author{
The new name Lepidium barneoudianum is created to replace the illegitimate name Lepidium brevicaule \\ BARN., a posterior homonym of a European species \\ Karel Sutorý \\ Moravian Museum, Department of Botany, Hviezdoslavova 29a, 62700 Brno, Czech Republic. E-mail: \\ ksutory@mzm.cz
}

Lepidium barneoudianum Sutorý, nomen novum Lepidium brevicaule Barn., in Gay, Hist. Chile Bot. 1: 165, 1845, nom. illeg. substitutum non Lepidium brevicaule Hoppe ex W.D.J. Koch, Deutschl. Fl., ed. 3., 4: 519, 1833, = Lepidium brevicaule Hoppe, Flora 10: 564, 1827, nomen nudum

Syn.: Nasturtium brevicaule (Barn.) Kuntze, Revis. Gen. Pl. 2: 937, 1891

Type locality: Chile, Cordilleras de Coquimbo, $3,300 \mathrm{~m}$ a s.l. Holotype deposited in Paris (P), n.v. Photo 34548 of the series distributed by the Field Museum.

Lepidium brevicaule Barn. was described from north-central Chile by Gay (1845). This name is not legitimate because of the existence of the older homonym Lepidium brevicaule Hoppe ex W.D.J. Koch 1833, based on a European type distributed by Hoppe. Nowadays the following names are used for this European taxon at specific or infraspecific levels: Hutchinsia brevicaulis Hoppe ex Spreng., Syst. Veg., 2: 863, 1825; H. alpina subsp. brevicaulis (Hoppe ex Spreng.)Arcang., Comp. F. Ital. 58, 1882; Pritzelago brevicaulis (Hoppe ex Spreng.) Kuntze, Revis. Gen. 1: 35 1891; P.alpina subsp. brevicaulis (Hoppe ex Spreng.)Greuter \& Burdet, Willdenowia 15: 69, 1985.
Thellung (1906), in his monographic study of the genus Lepidium, was aware of both names, but the European name is cited (page 316) under "Species ex genere Lepídio excludendae" and referred to as "Hutchinsia alpina (L.) R. Br. var". Barnéoud's species is cited among 42 species that appear in Hitschcock's monograph of South American species of the genus Lepidium (Hitschcock 1945).

The Chilean species L. brevicaule Barn. is cited not only in $19^{\text {th }}$ century sources (e.g. Reiche 1895), appearing also in recent checklists of this region (e.g. Marticorena \& Quezada 1985; Arroyo et al. 1990). According to the Art 53.1 of ICBN (Greuter et al. 2000) "A name of a family, genus or species, unless conserved or sanctioned, is illegitimate if it is a later homonym, that is, if it is spelled exactly like a name based on a different type that was previously and validly published for a taxon of the same rank". The new name Lepidium barneoudianum is therefore proposed in this case.

\section{ACKNOWLEDGMENTS}

The work on this problem was supported by a grant (RK01P0OMG021) from the Ministry of Culture of the Czech Republic. 
Gayana Bot. 60(2), 2003

\section{REFERENCES}

Arro yo, M.T.K., C. Marticorena \& M. Muñoz. 1990: A checklist of the native annual flora of continental Chile. Gayana Botanica 47: 119-135.

GAY, C. 1845: Historia fisica y politica de Chile, segun documentos adquiridos en esta republica durante doce anos de residentia en ella, y publicada bajo los auspicios del supremo gobierno. Botánica (Flora Chileana). Vol. 1. Faine \& Thunot, Paris. $496 \mathrm{pp}$.

Greuter W., J. McNeill, F.R. Barrie, H.M. Burdet, V. Demoulin, T.S. Filgueiras, D.H. Nicolson, P.C. Silva, J.E. Skog, P. Trehane, N.J. Turland \& D.L. Hawksworth. 2000: International Code of
Botanical Nomenclature (Saint Louis Code), Regnum Vegetabile 138, Königstein. 474 pp.

Нiтsснсоск, C.L. 1945: South American species of Lepidium. Lilloa 11: 75-134.

Kосн, W.D.J. 1833: Deutschlands Flora. Vol. 4. Ed. 3. Friedrich Wilmans, Fankfurt am Mein. 744 pp.

Marticorena, C. \& M. Quezada. 1985: Catálogo de la flora vascular de Chile. Gayana Botanica 42: 1157.

Reiche, C. 1895: Flora de Chile. Vol. 1/1. Imprenta Cervantes. Santiago de Chile. 353 pp.

Thellung, A. 1906: Die Gattung Lepidium (L.) R.Br. Eine monographische Studie Mitteilungen aus dem botanischen Garten und Museum der Universität Zürich 28: 1-340. (Denkschriften der Schweizerischen naturforschenden Gesellschaft. 41: 1-340). 